\title{
A laparoszkópos és a nyitott mútéti technikával operált méhtestrák progressziómentes és teljes túlélési eredményeinek összehasonlítása
}

\author{
Póka Róbert dr. - Baradács István oh. \\ Debreceni Egyetem, Általános Orvostudományi Kar, Szülészeti és Nőgyógyászati Intézet, \\ Nógyógyászati Onkológiai Nem Önálló Tanszék, Debrecen
}

\begin{abstract}
Bevezetés: A közelmúltban megjelent publikációk szerint a korai méhnyakrák miatt végzett endoszkópos kiterjesztett mütétek gyógyulási eredményei rosszabbak, mint a nyitott mútétekéi, s ez felveti a méhtestrák kezelésében is terjedő endoszkópos technológia értékelésének szükségességét.

Célkitüzés: Az endoszkópos és a nyitott mútéti technikával kezelt méhtestrák gyógyulási eredményeinek összehasonlítása.

Módszer: Retrospektív vizsgálatban a 2013 és 2019 között méhtestrák miatt végzett műtétek klinikopatológiai adatainak és eredményességének elemzésére került sor. A mútéti kezelés eredményességét a progressziómentes és a teljes túlélés értékelésével végeztük. A vizsgált csoportok prognosztikai tényezőinek különbségeit $\chi^{2}$ - és $t$-próbával hasonlítottuk össze. A daganatprogresszió előfordulását és az alapbetegség okozta halálesetek előfordulási gyakoriságát Cox-modellben értékeltük, a progressziómentes és a teljes túlélési görbék összehasonlítására a Kaplan-Meier-módszert alkalmaztuk.

Eredmények: Az endometrioid, serosus papillaris, kevert Müller-sejtes, adenosquamosus és egyéb szövettani típusok előfordulási aránya az endoszkópos és a nyílt mútéti csoportban lényegesen nem különbözött $(\mathrm{p}=0,3356)$. A Gl, G2, G3 differenciáltsági fokú folyamatok előfordulási aránya az endoszkópos és a nyílt mútéti csoportban jelentősen különbözött ( $\mathrm{p}=0,0036)$. A patológiai stádiumok (IA, IB, II, IIIA, IIIB, IIIC1, IIIC2) megoszlása az endoszkópos és a nyílt mútéti csoportban jelentősen különbözött $(\mathrm{p}=0,0048)$. Az eltávolított nyirokcsomók átlagos száma magasabb volt a nyitott mútéttel operált csoportban $(14,3$ vs. 9,3, p<0,0001). A progresszív betegség gyakorisága magasabb volt a nyitott mútéti csoportban, de a betegségspecifikus halálesetek előfordulási gyakorisága jelentősen nem különbözött a két csoportban (recidíva 2/120 vs. 29/345, p =0,01; halálozás $2 / 120$ vs. 17/345, p = 0,12); a laparoszkópos esetek progressziómentes és teljes túlélése nem különbözött jelentősen a nyitott mútéttel operált esetekétól (progresszió laparoszkópos vs. nyílt mútét: $\mathrm{HR}=0,36,95 \% \mathrm{CI}=0,084-1,538$; halálozás laparoszkópos vs. nyílt mütét: $\mathrm{HR}=0,603,95 \% \mathrm{CI}=0,135-2,693$ ).

Következtetés: Az endoszkópos technikával operált méhtestrák progressziómentes és teljes túlélése nem rosszabb, mint a nyílt mútéti technikával kezelt betegeké.
\end{abstract}

Orv Hetil. 2020; 161(10): 382-388.

Kulcsszavak: méhtestrák, endoszkópos és nyitott mútét, progressziómentes és teljes túlélés

\section{Comparison of progression-free and overall survival between endometrial cancer patients treated with laparoscopic and open surgical techniques}

Introduction: Recently published unfavourable results of endoscopic radical surgery for early-stage cervical cancer compared to open surgery raises the need for auditing treatment results of endoscopic staging surgery for endometrial cancer.

Aim: Comparison of progression-free and overall survival (PFS and OS) between endometrial cancer patients treated with laparoscopic (LSC) and open surgical techniques.

Method: Retrospective analysis was performed to compare clinicopathological and survival data of endometrial cancer patients who had either laparoscopic or open staging surgery between 2013 and 2019 at the Gynaecological Oncology Unit of the University of Debrecen, Hungary. Distribution of the most relevant prognostic factors were compa- 
red with $\chi^{2}$ and $t$-tests. Frequencies of progressive disease and disease-specific deaths were compared in the Cox-model, while progression-free and overall survival curves were compared with the Kaplan-Meier method.

Results: The frequency of endometrioid, serous papillary, mixed Müllerian, adenosquamous and other histological types in the laparoscopic and open groups were similar $(\mathrm{p}=0.3356)$. The frequency of grade 1,2 and 3 tumours in the endoscopic and open groups showed significant differences $(\mathrm{p}=0.0036)$. Pathological stage-distribution (IA, IB, II, IIIA, IIIB, IIIC1, IIIC2) of endoscopic cases and open cases was also statistically different $(\mathrm{p}=0.0048)$. The mean number of removed lymph-nodes was higher in the open surgery group $(14.3 v s .9,3, \mathrm{p}<0.0001)$. The frequency of recurrence did not show significant difference between the two groups, in contrast to the frequency of diseasespecific deaths $(2 / 120$ vs. $29 / 345, \mathrm{p}=0.01 ; 2 / 120$ vs. $17 / 345, \mathrm{p}=0.12)$. In the Cox-model, progression-free survival and overall survival showed a hazard ratio favouring laparoscopic surgery, however, the range of $95 \%$ confidence intervals showed no statistical significance (PFS LSC vs. open: HR $=0.36,95 \% \mathrm{CI}=0.084-1.538$; OS LSC $v s$. open: $\mathrm{HR}=0.603,95 \% \mathrm{CI}=0.135-2.693)$.

Conclusion: Progression-free and overall survival of endoscopically staged endometrial cancer is not worse than those of patients staged with open surgery.

Keywords: endometrial cancer, endoscopic and open surgery, progression-free and overall survival

Póka R, Baradács I. [Comparison of progression-free and overall survival between endometrial cancer patients treated with laparoscopic and open surgical techniques]. Orv Hetil. 2020; 161(10): 382-388.

(Beérkezett: 2019. október 27.; elfogadva: 2019. november 17.)

\section{Rövidítések}

ASTEC $=($ A Study in the Treatment of Endometrial Cancer $)$ az endometriumcarcinoma kezelését vizsgáló tanulmány; $\mathrm{CI}=$ (confidence interval) konfidenciaintervallum; ESGO $=(\mathrm{Eu}-$ ropean Society of Gynaecological Oncology) Európai Nőgyógyász Onkológusok Társasága; ESMO = (European Society for Medical Oncology) Európai Klinikai Onkológiai Társaság; $\mathrm{ESTRO}=($ European Society for Radiotherapy and Oncology $)$ Európai Sugárterápiás és Onkológiai Társaság; FIGO = (Fédération Internationale de Gynécologie et d'Obstétrique) Nemzetközi Szülészeti és Nőgyógyászati Szövetség; GOG = (Gynecologic Oncology Group) Nőgyógyászati Onkológiai Munkacsoport; HR = (hazard ratio) kockázati arány; SEPAL = (Survival Effect of Para-Aortic Lymphadenectomy) a paraaorticus lymphadenectomia hatása a túlélésre

A kisebb morbiditás és rövidebb kórházi ápolási igény révén az endoszkópia alkalmazása minden mútétes szakmában terjed. Hazai konszenzus alapján ma már a májáttétek mútéti kezelésében is van helye az endoszkópos sebészetnek, annak ellenére, hogy a mútéti technikát bemutató hazai beszámolók egyelőre túlélési adatokat nem közöltek [1, 2]. A nőgyógyászati onkológia legnagyobb meglepetése volt 2018-ban a korai méhnyakrák minimálisan invazív mütéti kezelésének a nyitott mútétekhez képest kedvezőtlenebb túlélési eredménye [3]. A randomizált vizsgálat következtetéseit megerősítette egy lényegesen magasabb esetszámú retrospektív elemzés is [4]. Joggal vetődik fel a kérdés, hogy vajon méhtestrák esetében hogyan viszonyulnak egymáshoz a két technológia túlélési eredményei. Az Orvosi Hetilap egy irodalmi áttekintés keretében, 2010-ben már foglalkozott a laparoszkópia szerepével a méhtestrák kezelésében, de túlélési eredményeket is elemző hazai vizsgálat még nem került közlésre [5].
Elsőként 2005-ben Tozzi és mtsai, Zorlu és mtsai, valamint Zullo és mtsai számoltak be a méhtestrák mútéti kezelésében alkalmazott endoszkópos és nyitott mútéti technológia hatékonyságának és biztonságosságának öszszehasonlításáról [6-8]. E kisebb esetszámú tanulmányok egybehangzóan igazolták, hogy az endoszkópos technológia alkalmazása kevesebb szövődménnyel, kisebb vérveszteséggel, rövidebb hospitalizációval és a stádiummeghatározás közel azonos klinikopatológiai eredményességével jellemezhető. Néhány évvel később már a kisebb esetszámú tanulmányok metaanalízise is megjelent, ami a fentiek megerósítésén túl a túlélési eredmények hasonlóságát is igazolta, de felhívta a figyelmet a követési idő viszonylag rövid tartamára [9]. A biztató eredmények hatására elkezdődtek a nagy esetszámú randomizált vizsgálatok is. A GOG LAP2 elnevezésű, III. fázisú randomizált vizsgálata szerint a méhtestrák eseteinek 76,3\%-ában a staging mútét laparoszkópos úton is kivitelezhető. Hat héttel a mútét után az életminőség kedvezőbb a laparoszkópos technikával operált csoportban, mint a nyitott mütéten átesett betegek esetében. A két csoport becsült 3 éves túlélése sorrendben 89,8\% és $89,9 \%$ volt. Mivel sem a recidívák gyakoriságában, sem a túlélésben nem voltak rosszabbak a laparoszkópos csoport eredményei, mint a nyitott mútéttel operáltakéi, a szerzők a méhtestrák mútéti kezelésében ezt a technológiát javasolják elsőként választandó módszerként [10]. Négy randomizált vizsgálat metaanalízise az endoszkópos mütétek hosszabb időtartamát, kevesebb mütéti vérveszteségét és a mútét utáni szövődmények alacsonyabb gyakoriságát állapította meg a nyitott mütétekhez viszonyítva. A progressziómentes és a teljes túlélésben nem volt kimutatható különbség. A követési adatok kiteljesedésekor levonható következtetések megjelenéséig a lapa- 
roszkópos staginget a nyitott mútét jó alternatívájának tartják a metaanalízis szerzői [11].

E vizsgálatokkal egyidejûleg jelentős vita folyt a szakmán belül arról, hogy szükséges-e egyáltalán a szisztematikus lymphadenectomia elvégzése endometriumcarcinomában. Trimble és mtsai még az ezredforduló előtti retrospektív vizsgálatukban 9185 méhtestrákos eset adataival támasztották alá azon következtetésüket, hogy a válogatás nélküli I. stádiumú esetekben a lymphadenectomia nem javítja az 5 éves túlélést, a grade 3 -as betegek túlélése azonban szisztematikus lymphadenectomiával jelentősen növelhető $(0,89$ vs. $0,81, p=0,011)$ [12]. A kérdés eldöntésére tervezett randomizált tanulmány - az ASTEC-vizsgálat - szerint a lymphadenectomia nem javítja a méhtestrák túlélését. A vizsgálatot számos kritika érte a szövettani típusok változatossága, a lymphadenectomia következetlen és gyakori elégtelen alkalmazása, valamint a bevont esetek alacsony rizikójú volta miatt [13]. A SEPAL-vizsgálatban a szisztematikus kismedencei lymphadenectomiát is magában foglaló staging mütétek kiegészítése paraaorticus lymphadenectomiával jelentős túlélési előnyt igazolt [14]. Ezt a vizsgálatot is számos kritika érte, melyek egybehangzóan úgy értékelték az eredményeket, hogy a szisztematikus kismedencei lymphadenectomia kiegészítése paraaorticus lymphadenectomiával azért javította a túlélést, mert a nyirokáttétes esetek kemoterápiában is részesültek. Az alcsoportvizsgálatok eredményei valóban arra utalnak, hogy a magas rizikójú esetek túlélési előnyéhez jelentősen hozzájárult az adjuváns kemoterápia.

Vizsgálatunk célja a Debreceni Egyetem Általános Orvostudományi Karának Nőgyógyászati Onkológiai Tanszékén 2013 és 2019 között méhtestrák miatt végzett, nyílt és laparoszkópos staging mütétek eredményességének összehasonlítása volt.

\section{Módszer}

Retrospektív vizsgálatban a 2013 és 2019 között méhtestrák miatt végzett mütétek klinikopatológiai adatainak és eredményességének elemzésére került sor. A műtéti kezelés eredményességét a progressziómentes és a teljes túlélés értékelésével végeztük. A vizsgált csoportok prognosztikai tényezőinek különbségeit $\chi^{2}$ - és $t$-próbával hasonlítottuk össze. Az adjuváns kezelések alkalmazásában az ESGO-ESMO-ESTRO hatályos konszenzusos protokolljának megfelelően jártunk el. A daganatprogresszió előfordulását és az alapbetegség okozta halálesetek előfordulási gyakoriságát Cox-modellben értékeltük, a progressziómentes és a teljes túlélési görbék összehasonlítására a Kaplan-Meier-módszert alkalmaztuk.

\section{Eredmények}

A vizsgált időszak során az endoszkópos staging mútétek aránya folyamatosan emelkedett (1. táblázat). Az endoszkópos mütéttel kezelt betegek átlagos életkora ala-
1. táblázat $\mid$ Endometriumcarcinoma nyílt és laparoszkópos staging műtéte inek száma 2013 és 2019 között

\begin{tabular}{lccc}
\hline Év & Laparoszkópos & Nyílt & Összesen \\
\hline 2013 & 1 & 45 & 46 \\
2014 & 1 & 57 & 58 \\
2015 & 9 & 65 & 74 \\
2016 & 21 & 57 & 78 \\
2017 & 37 & 41 & 78 \\
2018 & 36 & 52 & 88 \\
$2019^{*}$ & 15 & 28 & 43 \\
\hline Összesen & 120 & 345 & 465 \\
\hline
\end{tabular}

*első félévi adat

2. táblázat |A klinikopatológiai tényezők megoszlása nyílt és laparoszkópos staging mútéten átesett endometriumcarcinomás esetekben

\begin{tabular}{lrrr}
\hline Klinikopatológiai tényező & Nyílt & Laparoszkópos & $\mathrm{p}$ \\
\hline Átlagéletkor (év) & 63,1 & 60,3 & 0,020 \\
\hline Szövettani típus & & & 0,336 \\
$\quad$ Endometrioid & 296 & 113 & \\
Serosus papillaris & 19 & 5 & \\
Kevert Müller-sejtes & 11 & 0 & \\
Adenosquamosus & 7 & 2 & \\
Endometrialis stroma sarcoma & 6 & 0 & \\
Leiomyosarcoma & 3 & 0 & \\
Világossejtes & 1 & 0 & \\
Villoglandularis & 1 & 0 & \\
Leydig-sejtes & 1 & 0 & \\
\hline
\end{tabular}

Differenciáltsági fok 0,004

$\begin{array}{rrr}\text { G1 } & 97 & 42 \\ \text { G2 } & 172 & 68 \\ \text { G3 } & 76 & 10\end{array}$

Patológiai stadium (FIGO, 2010)

IA

IB

$144 \quad 71$

II

63

13

72

27

IIIA

17

IIIB

$$
9
$$

2

IIICl

$22 \quad 5$

IIIC2

$18 \quad 0$

\begin{tabular}{lccc}
\hline Ér-, nyirokér-invázió & $48 / 345$ & $4 / 120$ & 0,002 \\
\hline $\begin{array}{l}\text { Az eltávolított nyirokcsomók } \\
\text { átlagos száma }\end{array}$ & 14,3 & 9,3 & 0,001 \\
\hline
\end{tabular}

\begin{tabular}{lccc}
\hline Örszemnyirokcsomó-diagnosztika & $8 / 345$ & $29 / 120$ & 0,001 \\
\hline $\begin{array}{l}\text { A pozitív nyirokcsomók átlagos } \\
\text { száma }\end{array}$ & 0,382 & 0,067 & 0,001 \\
\hline
\end{tabular}

Medián követési idő (hónap)

25,4

13,7

0,001

FIGO = Nemzetközi Szülészeti és Nőgyógyászati Szövetség 
csonyabb volt, mint a nyitott mútéttel kezelteké (2. táblázat). Az endometrioid, serosus papillaris, kevert Müller-sejtes, adenosquamosus és egyéb szövettani típusok előfordulási aránya az endoszkópos és a nyitott mútéti csoportban lényegesen nem különbözött. A G1, G2, G3 differenciáltsági fokú folyamatok előfordulási aránya az endoszkópos és a nyitott mütéti csoportban jelentősen különbözött. A patológiai stádiumok (IA, IB, II, IIIA, IIIB, IIIC1, IIIC2) megoszlása az endoszkópos és a nyitott mütéti csoportban jelentősen különbözött. Az eltávolított nyirokcsomók átlagos száma magasabb volt a nyitott mütéttel operált csoportban, de az endoszkópos csoportban lényegesen gyakrabban végeztünk őrszemnyirokcsomó-diagnosztikát szisztematikus lymphadenectomia nélkül. A progresszív betegség gyakorisága magasabb volt a nyílt mútéti csoportban (2/120 vs. $29 / 345, p=0,01)$, de a betegségspecifikus halálesetek előfordulási gyakorisága jelentősen nem különbözött a két csoportban $(2 / 120$ vs. $17 / 345, \mathrm{p}=0,12)$. A laparoszkópos esetek progressziómentes túlélése (1.ábra) és teljes túlélése (2. ábra) nem különbözött jelentősen a nyitott mütéttel operált esetekétől (daganatprogresszió laparoszkópos vs. nyílt mütét esetén: $\mathrm{HR}=0,36,95 \% \mathrm{CI}$ 0,084-1,538; betegségspecifikus halálozás laparoszkópos vs. nyílt mütét esetén: $\mathrm{HR}=0,603,95 \%$ CI $0,135-$ $2,693)$.

\section{Megbeszélés}

Creasman és mtsai 1987-ben a méhtestrák terjedésének jellegzetességeit és prediktorait vizsgáló nagy esetszámú tanulmánya javasolta elsőként a 'staging mütét' koncepcióját [15]. Manapság is a tumorgrade, a szövettani típus, a myometriuminvázió mélysége, a lymphovascularis terek érintettsége, az adnexumok érintettsége és az extrauterin terjedésre utaló egyéb jelek képezik a nyirokcsomó-metasztázis legfontosabb prediktorait. E tényezők meghatározása a kuratív mútét célját is jelenti, hiszen ezek határozzák meg az adjuváns kezelés optimális módszerét. A laparoszkópos technikának a méhtestrák staging mütéteiben való alkalmazása is ugyanezen célokat szolgálja. Joggal vetődik fel a kérdés, hogy a végeredmény, azaz a túlélés tekintetében hogyan viszonyul egymáshoz a laparoszkópos és a nyílt mütéti technika.

A korai, kis esetszámú összehasonlító vizsgálatok rendre megerősítették a laparoszkópos technika alacsonyabb morbiditását és a rövidebb hospitalizációt, túlélési adatok nélkül [6-8, 16]. Chu és mtsai 2002 és 2012 között operált 151 endometriumcarcinomás beteg (70 laparoszkópos és 81 nyílt mütét) adatait elemezték. A két csoport demográfiai és prognosztikai paramétereiben nem volt jelentős különbség. A laparoszkópos csoportban kevesebb volt a mútéti vérveszteség, hosszabb a mütéti időtartam, kisebb az eltávolított méh tömege, kevesebb az eltávolított nyirokcsomók száma és rövidebb a hospitalizáció tartama, mint a nyílt műtéti csoportban. A betegség kiújulásának gyakorisága közel azo-

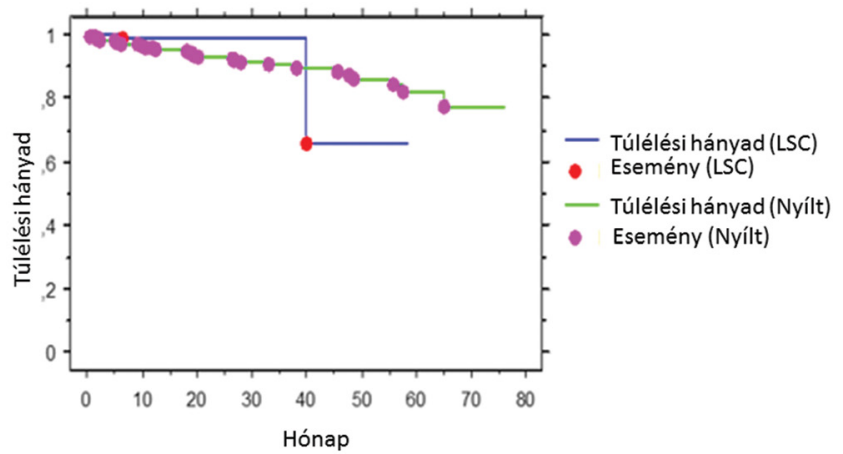

\begin{tabular}{l|l} 
1. ábra & Laparoszkópos és nyílt mútéttel kezelt endometriumcarcinomás \\
&
\end{tabular} esetek progressziómentes túlélése

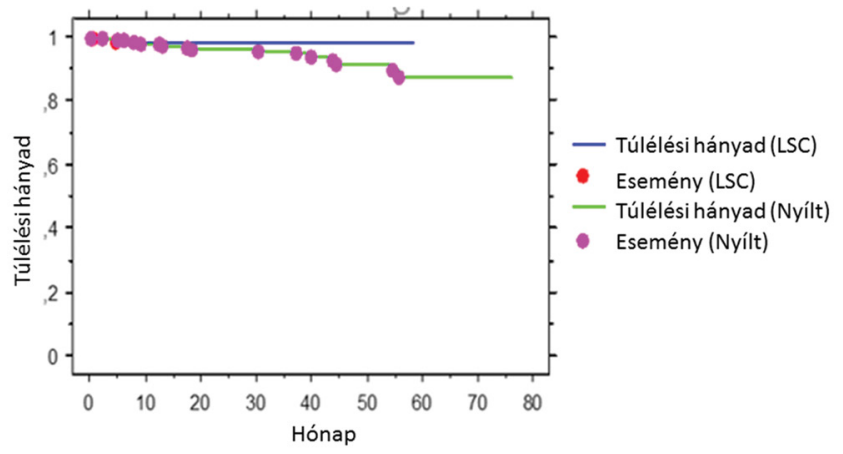

2. ábra $\quad$ Laparoszkópos és nyílt mútéttel kezelt endometriumcarcinomás esetek teljes túlélése

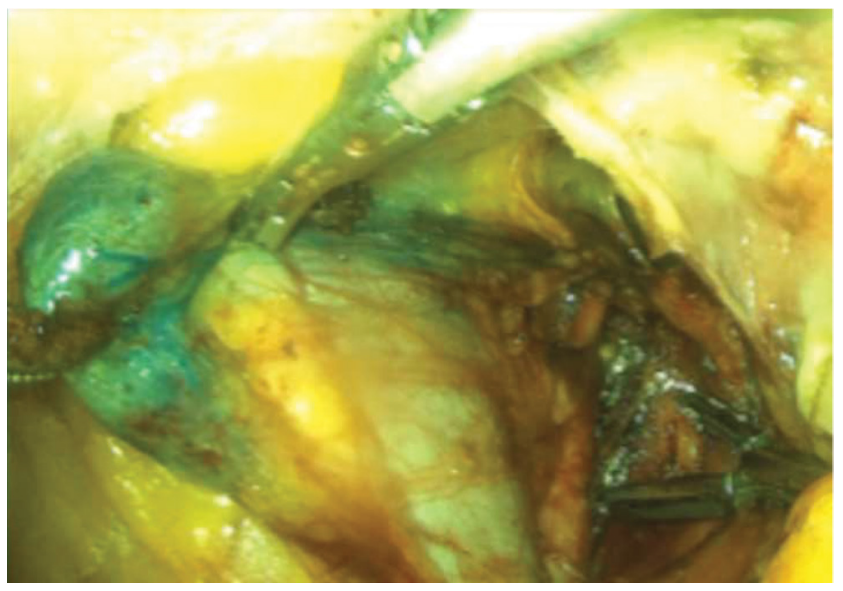

3. ábra Patentkék festékkel azonosított őrszemnyirokcsomó a bal oldali arteria iliaca externa felszínén

nos volt a két csoportban $(2,9 \%$ és $2,5 \%, \mathrm{p}=0,882)$. A követési idő alatt a nyílt mütétes csoportban két, a laparoszkópos csoportban egy betegségspecifikus haláleset fordult elő [17]. Egy tajvani munkacsoport 365, IA-IIIC stádiumú méhtestrákos eset mútéti (129 nyílt, 86 robotasszisztált, 150 laparoszkópos) kezelésének eredményeiről számolt be. Eredményeik szerint nemcsak a mütéti vérveszteség és a hospitalizáció tartama csökkenthető a minimálinvazív technikákkal, hanem magának a mütétnek az időtartama is. A szerzők nem észleltek 
különbséget a három mútéti technika között, sem a progressziómentes túlélésben, sem a teljes túlélésben [18]. Tanaka és mtsai a 2008 és 2016 között végzett 54 laparoszkópos és 99 nyílt mütétes esettel szerzett tapasztalatokról számoltak be. Az életkor, a stádiummegoszlás, a szövettani típus megoszlása és a testtömegindex tekintetében nem különbözött a két csoport. A betegség kiújulási aránya 7,4\% és 14,3\% volt, de statisztikailag ez a különbség nem volt szignifikáns [19]. Beck és mtsai 3712, méhtestrákos eset adataival vizsgálták a robotaszszisztált, a laparoszkópos és a nyitott mútéti kezelés biztonságosságát. A hospitalizáció tartama sorrendben 1,5, 1,6 és 3,9 nap volt. Az újrafelvétel gyakorisága is a nyitott mútétes csoportban volt a legmagasabb, a robotasszisztált és a laparoszkópos csoport között nem volt jelentős különbség. Az onkológiai hatékonyságra vonatkozó adatot (progressziómentes túlélés, teljes túlélés) a tanulmány nem közölt [20]. Egy hasonló prospektív vizsgálatban Ansar és mtsai nem találtak jelentős különbséget a laparoszkópos és a nyílt mütétes csoport szövődményrátája között, és az eltávolított nyirokcsomók számában sem volt statisztikailag jelentős különbség. Az onkológiai kezelés hatékonyságára vonatkozó összehasonlítás ebben a vizsgálatban sem történt meg [21]. Nezhat és mtsai a laparoszkópos és a nyílt staging mütétek eredményeit összehasonlító korai tanulmányában túlélésbeli különbség nem volt kimutatható. A 36 és 30 hónapos medián követési idő során a betegség kiújulását a 67 laparoszkópos eset 7,7\%-ában, míg a 127 nyílt mútétes eset 16\%-ában regisztrálták. Az 5 éves teljes túlélésben nem volt kimutatható különbség a két csoport között [22].

Saját vizsgálatainkban a laparoszkóppal végzett staging mútétek után 120-ból 2 esetben fordult elő recidíva, míg a nyílt mứtéttel operált 345 eset közül 29 betegnél újult ki a daganat a megfigyelési idő alatt. A különbség statisztikailag jelentős volt, ezt azonban vélhetően a szövettani típusokban és a differenciáltsági fok eloszlásában kimutatott különbség is magyarázhatja.

Park és mtsai metaanalízise 24, robotasszisztált vs. nyílt hysterectomia összehasonlítását célzó vizsgálat és 24 , robotasszisztált $v s$. nyílt hysterectomia összehasonlítását végző vizsgálat adatait összegezte. A minimalinvazív technikák konzekvensen kevesebb vérveszteséggel és hosszabb mútéti idővel jártak, de a nyílt mütétekhez képest gyakrabban követte őket csonkdehiscentia. A betegségmentes és a teljes túlélést az első összehasonlításban két, a második összehasonlításban pedig három tanulmány vizsgálta, de klinikailag érdemleges különbséget egyik összehasonlításban sem tudtak kimutatni a két-két mûtéti módszer között [23].

A 2010 előtti FIGO-beosztás szerinti I. és IIa stádiumú esetek 2 : 1 arányú véletlen besorolású vizsgálatában 1696 betegnél laparoszkópos úton, 920 betegnél pedig nyitott mütéttel végezték el a hysterectomiát, a salpingooophorectomiát, a kismedencei mosófolyadék cytologiáját, valamint a kismedencei és paraaorticus lymphadenec- tomiát magában foglaló staging mütétet [24]. Az 59 hónapos medián követési idő elteltével a laparoszkópos csoportban 210, a nyílt mútétes csoportban pedig 99 recidíva fordult elő, a halálesetek száma pedig sorrendben 229 és 121 volt. A Kaplan-Meier-módszerrel becsült 5 éves túlélés a két karon azonos $(89,8 \%)$ volt.

Tanulmányunkban a laparoszkópos esetek progreszsziómentes és teljes túlélése nem különbözött jelentősen a nyitott mútéttel operált esetekétől (a betegség progressziója laparoszkópos vs. nyílt mútét esetén: $\mathrm{HR}=$ 0,36, 95\% CI 0,084-1,538; betegségspecifikus halálozás laparoszkópos vs. nyílt mútét esetén: $\mathrm{HR}=0,603,95 \%$ CI 0,135-2,693). A Kaplan-Meier-módszerrel becsült 2 éves progressziómentes és teljes túlélés mindkét csoportban $90 \%$ fölött volt (1. és 2. ábra). Tekintettel arra, hogy betegeink átlagos követési ideje 24,3 hónap volt, a két mütéti technika hasonlóan magas 5 éves, becsült túlélési eredményeit fenntartással kell értékelnünk.

Favero és mtsai az endometriumcarcinoma rossz prognózisú, serosus és világossejtes típusú, peritonealis érintettség nélküli esetei között vizsgálták a laparoszkópos és a nyílt staging mütét hatékonyságát. A méheltávolítást, kétoldali adnexectomiát, omentectomiát, valamint kismedencei és paraaorticus lymphadenectomiát magukban foglaló mútéteket (53 laparoszkópos, 36 nyílt műtét) 2009 és 2015 között végezték. A demográfiai és prognosztikai tényezők tekintetében hasonló volt a két csoport, kivéve a paraaorticus áttétek gyakoriságát, amely a laparoszkópos csoportban $26 \%$, a nyílt mútétes csoportban $13 \%$ volt $(p=0,04)$. Az adjuváns terápia gyakorisága hasonlóan magas volt a két csoportban, de a követési idő medián értéke csaknem egy évvel hosszabb volt a nyílt mútéti csoportban (38 vs. 47 hónap). Ennek ellenére sem a progressziómentes túlélésben, sem az 5 éves teljes túlélésben nem volt jelentős különbség a két csoport között (sorrendben $58 \%$ vs. $51 \%$ és $86 \%$ vs. $78 \%$ ). Következtetésük szerint e kifejezetten rossz prognózisú csoport mútéti kezelésében a laparoszkópos technika onkológiai szempontból kedvezőbb eredményt nyújt, mint a nyílt mútét [25].

Saját anyagunkban a rossz prognózisú szövettani típusok és 'high-grade' tumorok alcsoportjának elemzésére az alacsony esetszámok miatt nem volt lehetőségünk. Ilyen esetekben egyelőre a nyílt mütéti technikát preferáljuk az adekvát paraaorticus lymphadenectomia érdekében, valamint az extrauterin terjedés magasabb kockázata miatt.

A morbiditást fokozó felesleges lymphadenectomiák számának csökkentése már korábban is felmerült. A preoperatív képalkotók sem a nyirokcsomó-metasztázis előrejelzésében, sem a mély myometriuminvázió előrejelzésében nem mutatnak elégséges szenzitivitást és negatív prediktív értéket [26]. Ebből adódóan nem meglepő, hogy a méhtestrák staging mütéteinek evolúciójában egyre nagyobb figyelem fordul az örszemnyirokcsomódiagnosztika felé. Vizsgálati anyagunkban az eltávolított nyirokcsomók számában észlelt különbség is ebból adó- 
dik. Az alacsony rizikójú esetekben (endometrioid szövettani típus, Gl-2-es differenciáltsági fok, cervixérintettségre és extrauterin terjedésre nem utaló preoperatív képalkotók) esetén végeztünk őrszemnyirokcsomó-azonosítást az endoszkópos mútétek negyedében (3. ábra). Döntően ennek tudható be, hogy az átlagos nyirokcsomószám ezen a karon kevesebb volt. Az endoszkópos lymphadenectomia hatékonyságát igazolja, hogy a laparoszkópos csoport G3-as endometrioid és nonendometrioid esetei között $(\mathrm{n}=32)$ az eltávolított nyirokcsomók átlagos száma 15,2 volt, ami statisztikailag is szignifikánsan magasabb, mint a nyílt mütétes esetek átlagos nyirokcsomószáma.

Jogos lehet az a megállapítás, hogy az endoszkópos csoport kedvezőbb prognosztikai összetétele ellenére hasonlónak bizonyult túlélés a laparoszkópia rosszabb eredményeire utalhat. Ez a megállapítás azonban azért nem megalapozott, mert a két csoport stádiummegoszlásában nem volt különbség, és az endoszkópos csoport követési ideje lényegesen rövidebb volt, mint a nyílt mütétes eseteké. Az összehasonlítás leszúlkítése az elmúlt három évben operált esetekre a két csoport hasonlóságát mutatta mind a daganatprogresszió előfordulását (1/69 vs. $18 / 232, \mathrm{p}=0,058)$, mind pedig a betegségspecifikus halálesetek gyakoriságát $(2 / 69$ vs. $15 / 232, \mathrm{p}=0,260)$ illetően.

Tudomásunk szerint jelen tanulmányunk az első olyan hazai közlemény, amely az endometriumcarcinoma laparoszkópos staging mútéteinek túlélési eredményeirôl is számot ad. Anyagunkban, különösen a laparoszkópos technikával végzett mútétek kapcsán, jelentős számban történt sikeres őrszemnyirokcsomó-azonosítás, többségben negatív intraoperatív szövettani eredménnyel. A prognosztikai tényezők megoszlásában leírt különbségek hatásának tisztázására további vizsgálatok szükségesek. Ennek legbiztosabb módszere egy multicentrikus randomizált vizsgálat lehet.

\section{Következtetés}

Megállapíthatjuk, hogy a preoperatív képalkotó vizsgálatokkal extrauterin terjedést nem mutató endometriumcarcinoma laparoszkópos staging mütétét követően recidíva ritkábban fordul elő, mint a nyílt mütéttel operált méhtestrákos esetek között. A laparoszkóppal operált endometriumcarcinomás esetek progressziómentes és teljes túlélése nem mutat jelentős különbséget a nyílt mútéttel operált betegek túléléséhez képest.

Anyagi támogatás: A közlemény megírása anyagi támogatásban nem részesült.

Szerzôi munkamegosztás: P. R.: A tanulmány tervezése, betegellátás, a kézirat elkészítése. P. R., B. I.: Mütéti és követési adatok összegyüjtése és feldolgozása, irodalomkutatás. A cikk végleges változatát mindkét szerző elolvasta és jóváhagyta.

Érdekeltségek: A szerzőknek nincsenek érdekeltségeik.

\section{Irodalom}

[1] Hungarian Hepato-Pancreatico-Biliar Study Group. Complex therapy of colorectal metastases. [Magyar Hepato-PancreaticoBiliaris (HPB) Kutatócsoport. Colorectalis májmetastasisok komplex kezelése.] Orv Hetil. 2019; 160(Suppl 2): S2-S20. [Hungarian]

[2] Sztipits T, Mészáros P, Dubóczki Zs, et al. Comparison of open and laparoscopic minor liver resections for malignant tumours based on the experience of the first 50 cases. [Malignus májdaganatok miatt végzett laparoszkópos minor reszekciók eredményei az első 50 eset kapcsán.] Orv Hetil. 2019; 160: 104-111. [Hungarian]

[3] Ramirez PT, Frumovitz M, Pareja R, et al. Minimally invasive versus abdominal radical hysterectomy for cervical cancer. $\mathrm{N}$ Engl J Med. 2018; 379: 1895-1904.

[4] Melamed A, Margul DJ, Chen L, et al. Survival after minimally invasive radical hysterectomy for early-stage cervical cancer. $\mathrm{N}$ Engl J Med. 2018; 379: 1905-1914.

[5] Langmár Z, Szabó I. Role of laparoscopy in the treatment of early endometrial cancer. [A laparoszkópia szerepe a korai stádiumú méhtestrák sebészi kezelésében.] Orv Hetil. 2010; 151: 1748-1752. [Hungarian]

[6] Tozzi R, Malur S, Koehler C, et al. Laparoscopy versus laparotomy in endometrial cancer: first analysis of survival of a randomized prospective study. J Minim Invasive Gynecol. 2005; 12: 130-136.

[7] Zorlu CG, Simsek T, Ari ES. Laparoscopy or laparotomy for the management of endometrial cancer. J Soc Laparoendosc Surg. 2005; 9: 442-446.

[8] Zullo F, Palomba S, Russo T, et al. A prospective randomized comparison between laparoscopic and laparotomic approaches in women with early stage endometrial cancer: a focus on the quality of life. Am J Obstet Gynecol. 2005; 193: 1344-1352.

[9] Palomba S, Falbo A, Mocciaro R, et al. Laparoscopic treatment for endometrial cancer: a meta-analysis of randomized controlled trials (RCTs). Gynecol Oncol. 2009; 112: 415-421.

[10] Walker JL, Piedmonte MR, Spirtos NM, et al. Laparoscopy compared with laparotomy for comprehensive surgical staging of uterine cancer: Gynecologic Oncology Group Study LAP2. J Clin Oncol. 2009; 27: 5331-5336.

[11] Ju W, Myung SK, Kim Y, et al. Comparison of laparoscopy and laparotomy for management of endometrial carcinoma: a metaanalysis. Int J Gynecol Cancer 2009; 19: 400-406.

[12] Trimble EL, Kosary C, Park RC. Lymph node sampling and survival in endometrial cancer. Gynecol Oncol. 1998; 71: 340-343.

[13] Kitchener H, Swart AM, Qian Q, et al. Efficacy of systematic pelvic lymphadenectomy in endometrial cancer (MRC ASTEC trial): a randomised study. Lancet 2009; 373: 125-136.

[14] Todo Y, Kato H, Kaneuchi M, et al. Survival effect of paraaortic lymphadenectomy in endometrial cancer (SEPAL study): a retrospective cohort analysis. Lancet 2010; 375: 1165-1172.

[15] Creasman WT, Morrow CP, Bundy BN, et al. Surgical pathologic spread patterns of endometrial cancer. A Gynecologic Oncology Group Study. Cancer 1987; 60 (8 Suppl): 2035-2041.

[16] Kalogiannidis I, Lambrechts S, Amant F, et al. Laparoscopy-assisted vaginal hysterectomy compared with abdominal hysterectomy in clinical stage I endometrial cancer: safety, recurrence, 
and long-term outcome. Am J Obstet Gynecol. 2007; 196: 248. el-248.e8.

[17] Chu LH, Chang WC, Sheu BC. Comparison of the laparoscopic versus conventional open method for surgical staging of endometrial carcinoma. Taiwan J Obstet Gynecol. 2016; 55: 188192.

[18] Chiou HY, Chiu LH, Chen CH, et al. Comparing robotic surgery with laparoscopy and laparotomy for endometrial cancer management: a cohort study. Int J Surg. 2015; 13: 17-22.

[19] Tanaka T, Terai Y, Hayashi S, et al. Comparison between laparoscopy and laparotomy in systematic para-aortic lymphadenectomy for patients with endometrial cancer: a retrospective multicenter study. J Gynecol Surg. 2017; 33: 105-110.

[20] Beck TL, Schiff MA, Goff BA, et al. Robotic, laparoscopic, or open hysterectomy: surgical outcomes by approach in endometrial cancer. J Minim Invasive Gynecol. 2018; 25: 986-993.

[21] Ansar PP, Ayyappan S, Mahajan V. Prospective nonrandomized comparative study of laparoscopic versus open surgical staging for endometrial cancer in India. Indian J Surg Oncol. 2018; 9: 133140.

[22] Acholonu UC Jr, Chang-Jackson SC, Radjabi AR, et al. Laparoscopy for the management of early-stage endometrial cancer: from experimental to standard of care. J Minim Invasive Gynecol. 2012; 19: 434-442.
[23] Park DA, Lee DH, Kim SW, et al. Comparative safety and effec tiveness of robot-assisted laparoscopic hysterectomy versus conventional laparoscopy and laparotomy for endometrial cancer: a systematic review and meta-analysis. Eur J Surg Oncol. 2016; 42: 1303-1314.

[24] Walker JL, Piedmonte MR, Spirtos NM, et al. Recurrence and survival after random assignment to laparoscopy versus laparotomy for comprehensive surgical staging of uterine cancer: Gynecologic Oncology Group LAP2 Study. J Clin Oncol. 2012; 30: 695-700.

[25] Favero G, Anton C, Le X, et al. Oncologic safety of laparoscopy in the surgical treatment of type II endometrial cancer. Int J Gynecol Cancer 2016; 26: 1673-1678.

[26] Chung HH, Kang SB, Cho JY, et al. Accuracy of MR imaging for the prediction of myometrial invasion of endometrial carcinoma. Gynecol Oncol. 2007; 104: 654-659.

(Póka Róbert dr., Debrecen, Nagyerdei krt. 98., 4032 e-mail: pokar@med.unideb.hu)

Az Orvosi Hetilap 2020; 161: 199. oldalán (5. szám) megjelent OH-kvízre két helyes megfejtés érkezett.

A beküldők: Dr. Bíró László (Budapest) és Dr. Somogyi Erzsébet (Budapest).

A nyerteseknek szívből gratulálunk.

\author{
A nyereményüket - egy, az Akadémiai Kiadó webáruházában \\ kedvezményes vásárlásra jogosító kupont - e-mailen küldjük el.
}

A cikk a Creative Commons Attribution 4.0 International License (https://creativecommons.org/licenses/by/4.0/) feltételei szerint publikált Open Access közlemény, melynek szellemében a cikk bármilyen médiumban szabadon felhasználható, megosztható és újraközölhető, feltéve, hogy az eredeti szerző és a közlés helye, illetve a CC License linkje és az esetlegesen végrehajtott módosítások feltüntetésre kerülnek. (SID_1) 